\title{
Hipólito de Roma e as heresias nos primeiros três séculos do cristianismo
}

\author{
Orientador: André Luiz Rodrigues da Silva \\ Mestrando: Marcelo Massao Osava \\ Área de Concentração: Teologia Sistemático-Pastoral \\ Linha de Pesquisa: Fé e Cultura \\ Projeto de Pesquisa: Aplicação da metodologia patrística ao pensamento \\ contemporâneo
}

Desde os primeiros séculos de sua existência o cristianismo convive com as heresias, que têm como principal característica a negação de uma verdade de fé devidamente ensinada pela Igreja Católica. A forma utilizada pelos bispos, sobretudo nos primeiros séculos, para determinar se estavam ou não diante de uma heresia, consistia em confrontar a doutrina ensinada com a regra de fé. Esta consistia em uma medida que se fundamentava na Sagrada Escritura e nos ensinamentos dos apóstolos. A doutrina que estivesse fora desta medida era considerada herética. A fim de evitar a proliferação de tais doutrinas e punir os que causavam desordens na comunidade, aos poucos foi se desenvolvendo na Igreja um código de leis. Hipólito de Roma, no século III, utilizou a regra de fé no combate aos hereges. É um personagem polêmico, seja em razão da autoria de suas obras ou por sua forte personalidade, historicamente considerado o primeiro antipapa em virtude do cisma com o Papa Calisto. Este trabalho demonstra a forma como Hipólito combatia as heresias que ameaçavam o cristianismo nos primeiros três séculos e como suas obras foram importantes na defesa da ortodoxia da fé, sobretudo a partir da Philosophumena. Pretende-se também apresentar Hipólito de Roma muito mais como um guardião da fé do que um cismático, pois ao final da vida, morre no exílio reconciliado com a Igreja, combatendo o bom combate e literalmente guardando a fé.

Palavras-chave: Heresia. Hipólito de Roma. Regra de Fé. Excomunhão. Philosophumena. 